\title{
The LAwyer's Role(s) IN Deliberative Democracy*
}

\author{
Carrie Menkel-Meadow**
}

\author{
"[Lawyers] serve as arbiters between the citizens." 1
}

\section{Introduction: Democratic Theory, Practice and Lawyers}

As legal theorists and academics we are drawn to grand meta-narratives about governing institutions, democracies, political theories and the role of law, citizens and elites in helping us to understand what are the best normative systems for us to use in governing ourselves. As a legal pragmatist and sometimes legal clinician and practitioner, I have long been concerned with how our grand theories operate in the empirical world. Can we make democratic theories really work? What are the conditions that foster democratic participation or good "democratic discourse" as current political theory describes it? What might be the role of the lawyer in constructing and facilitating "optimal" or "productive" democratic discourse? Are current institutions and current role enactments up to the task of fostering democracy or should we consider new forms of institutions and new legal and political roles? What challenges do new institutions and new roles present to our older, deeply structured institutions and roles - such as the Constitution, the political party system, the separation of powers, federalism and the adversary system?

As a conflict resolution theorist and practitioner, I have noted that the empirical world has changed greatly from the times in which most of our legal and political institutions were conceptualized and created. Political and legal issues are now often multi-partied and multi-issued, ${ }^{2}$ suggesting that older con-

* 드 2005 Carrie Menkel-Meadow

** Professor of Law, Georgetown University Law Center; Director, Georgetown-Hewlett Program in Conflict Resolution and Legal Problem Solving; Chair, CPR-Georgetown Commission on Ethics and Standards in ADR. Thanks to my hosts and friends at the William $S$ Boyd School of Law, University of Nevada, Las Vegas for the invitation to give this Saltman Lecture and for their comments, colleagueship, and hospitality, especially Jeffrey Stempel, Jean Sternlight, Joan Howarth, Lynne Henderson, Sylvia Lazos, Anne McGinley, Pam Mohr and Dean Dick Morgan. Various versions of this paper have been given at faculty colloquia and other events at Harvard Law School, Yale Law School, University of Maine Law School, Suffolk Law School, University of Miami, Rutgers-Camden Law School, my own Georgetown Law Center and various conferences on deliberative democracy and conflict resolution. I thank the participants at those events for many thoughtful comments and they will see their influence on me as this work continues to enfold. Thanks to Joshua Eizen and Ellen Connelly Cohen for research assistance.

1 Alexis de Tocqueville, Democracy in America 264 (J.P. Mayer ed., George Lawrence trans., 1st Perennial Library ed. 1969).

2 See Carrie Menkel-Meadow, The Trouble with the Adversary System in a Postmodern, Multicultural World, 38 WM. \& MARY L. Rev. 5 (1996). 
ceptions and institutions of dualisms and binary thinking (courts, political parties, federal or state governing units, and public/private spheres of responsibility) may be ill-suited to resolving, managing, or at least, handling, modern day legal and social problems. These problems may require input from a multiplicity of constituencies and coordinated action by a multiplicity of legal and political institutions. As some of us explore the possibilities of new institutions or more ad hoc processes, discussed below, which in turn suggest new and different roles for actors in these processes, others are exploring the different kinds of deliberations and activities that may occur in such different settings (e.g., Jon Elster's exploration of the differences in principled argument versus interest based bargaining in Constitution making). ${ }^{3}$ To what extent might we be able to re-shape some of our institutional structures to permit different kinds of democratic participation? To what extent are we "stuck" with the institutions our founders have given $\mathrm{us}^{4}$ which, in my view, continue to propagate unproductive oppositional, binary, polarized and adversarial approaches to more complex problems?

Implicit in these meta-questions is an obvious normative statement about the significance of the role of process in democratic deliberations and the quality of outcomes produced by such deliberations. Political philosophers and legal theorists, notably John Rawls, Ronald Dworkin, Jurgen Habermas, Frank Michaelman, Mark Tushnet, Cass Sunstein and Bruce Ackerman, among others, are currently exploring the important question of whether we can actually articulate a procedural vision of democracy or justice or whether in the end, it does boil down to our substantive and, likely, different preferences or values. In this paper, I commit myself to the search for an articulation of a process-oriented model of democratic deliberation and discourse, though I am concerned that in the end it might turn out to be "it's just the values, stupid!"5

In particular, in this paper I explore the use of alternative legal, political and social problem solving institutions that draw on conflict resolution theory and practice. These institutions suggest that forms of "consensus building,"

${ }^{3}$ See, e.g., Jon Elster, Strategic Uses of Argument, in B ARRIERs to Conflict Resolution (Kenneth J. Arrow et al. eds., 1995).

${ }^{4}$ Consider, if you will, the recent suggestion (published before the election of 2000 debacle) that Abigail Adams urged her husband to suggest to Thomas Jefferson, when the outcome of the 1796 election was still uncertain, that a coalition government of Federalists and Republicans should be formed. At least according to historian Joseph Ellis, John Adams made such a proposal to Jefferson who considered it and then turned it down when advised by James Madison that Jefferson's role was now to lead his party rather than to do business with "the other side." As Adams' Vice President, Jefferson retired to Monticello to plan the next competitive election. Imagine how different our governing structures might have turned out if history had given us a different set of actions in that all important formative time. See JosepH ElLis, Founding Brothers 179-83 (2000). Could we have had "coalition" governments with our non-Parliamentary structures?

5 As a committed process-oriented mediator, I found the events surrounding the presidential election of 2000 deeply troubling and potentially a defeat of the ideas proposed in this paper. Process surely ran amuck - all of it - including elections, court proceedings, possible peaceful mediation efforts and coalitions, interest based bargaining and ultimately the legitimacy of the whole system. This paper is a testament to my desire to push forward for alternative conceptions of decision making, enactments of power and leadership and democratic participation. 
which are both "principled" as well as based on "bargaining" models (when bargaining does not necessarily entail compromise), may provide useful models for democratic participation and political decision making sharply demarcated from the processes we currently use. Whether such alternative processes or institutions can be incorporated into or, in fact, challenge, traditional constitutional and other regulatory government structures remains to be fully argued and presented. Many legal scholars are currently engaged in that enterprise, most notably, Charles Sabel, Michael Dorf and other "constitutional experimentalists," as well as those studying the negotiated rule-making processes in administrative law (such as Cary Coglianese and Jody Freeman).

My contribution to this important theoretical and practical enterprise is to examine the possible role of the lawyer in these newer forms of structured democratic discourse. As a conflict resolution theorist, I have contributed to the growing literature on exploring new processes for dispute resolution, transaction creation, policy formation and political governance (following in the great tradition of the "jurisprude of dispute resolution," Lon Fuller, ${ }^{6}$ and many others, including Lawrence Susskind of MIT, one of the "fathers" of modern consensus building theory and practice ${ }^{7}$ ). Here, I suggest that a slightly different conception of the conventional lawyer's role might lend itself particularly well to assisting in the practice of new forms of democratic discourse. New processes and new institutions, whether they be ad hoc or made more permanent, require new roles, both for "democratic experimentalism" to be facilitated and also for effective evaluation. Who better than lawyers to attempt to facilitate (this is the crucial difference in role!) and test whether democratic discourse can occur in a highly contentious and substantively divided polity?

Must a lawyer "represent" a partisan interest to be a lawyer? So many of the conventional definitions of "lawyer" 8 assume that an attorney is an advo-

6 See Carrie Menkel-Meadow, Mothers and Fathers of Invention: The Intellectual Founders of $A D R, 16$ Ohio St. J Disp. Resol. 1 (2000); Lon L. Fuller, The Principles of Social. Order: SElected ESSAyS OF LoN L. Fuller (Kenneth I. Winston ed., 1981).

7 See The Consensus Building Handbook: A Comprehensive Guide to Reaching Agreement (Lawrence Susskind et al. eds., 1999) [hereinafter "The Consensus Building HaNDBooK."]. See especially Part I: An Alternative Robert's Rules of Order for Groups, Organizations, and Ad Hoc Assemblies That Want to Operate by Consensus.

8 "Lawyer":

A person learned in the law; as an attorney, counsel or solicitor; a person licensed to practice law. Any person who prosecutes or defends causes in courts of record or other judicial tribunals of the United States, or any of the States, or whose business it is to give legal advice or assistance in relation to any cause or matter whatever.

Black's Law Dictionary 799 (5th ed. 1979).

"Attorney at law":

One of a class of persons who are by license constituted officers of courts of justice, and who are empowered to appear and prosecute and defend, and on whom peculiar duties, responsibilities and liabilities are devolved in consequence. A quasi-judicial officer. Of course, the work of an attorney is not confined to appearances in court for prosecutions and defenses. A person acting professionally in legal formalities, negotiations or proceedings, by the warranty or authority of his clients is an attorney at law within the usual meaning of the term. The distinction between attorneys or solicitors and counsel or barristers is practically abolished in nearly all the states. While some men [sic] of the profession devote their time and talents to the trial of cases and others appear in court only rarely, the law imposes the same requirements for admission and the same standard of ethics for both classes. 
cate of a party, a client, a cause, even in a non-litigation matter, that we can hardly imagine that one acting as a lawyer could do so without a "position" or "client" or cause that requires defense, advocacy or "offensive" representation.

In this paper I will explore the idea of a "neutral" lawyer who may have neither "client" (in the conventional sense of client) ${ }^{9}$ to represent nor advocacy to perform, yet still be functioning fully as a lawyer or "learned professional" schooled in the law. Indeed, in this paper I will suggest that lawyers may be especially useful in performing a variety of "new" functions that depart from traditional conceptions of the lawyer's role, but which lawyers may be especially well suited to perform. It may be counter-cultural to think of lawyers as "consensus builders," rather than as advocates or makers of conflict, but that is just what effective lawyers must do. I will suggest that lawyers performing such roles may need to reconceptualize their professional roles, the goals they pursue, the activities they engage in and the rules and standards which might govern their behavior. Paradoxically, I also want to suggest that "neutral" lawyers (without clients or advocacy) may be well positioned to achieve or facilitate particular resolutions of legal problems that may contribute to "justice" even more effectively than "non-neutral" advocates.

Many commentators on American lawyers, from Tocqueville to more modern observers, have noted that lawyers may be particularly well suited to the inter-class, interest, issue, policy and partisan mediation that our society requires, not only to make laws, but to ensure smooth functioning of the ever diverse polity and the myriad interests that need to be reconciled to achieve social harmony and effective government. In the words of Anthony Kronman:

Lawyers serve private interests of clients but also care about integrity and justice of the legal system that defines public order within which these interests are pursued. In this way, they provide a link between the realms of public and private life, helping to rejoin what the forces of privatization are constantly pulling apart. ${ }^{10}$

Lawyers, then, can serve as mediators of the social order, helping to achieve the bargained for (traded), principled (reasoned) and creative (problem solved) arrangements that permit peaceful co-existence, social harmony and at its best, social justice to occur. This article suggests that if democratic participation is the means for achieving both public order and social justice, lawyers have a role to play in such processes, but the roles may be different from conventional roles of legal representation. Lawyers may represent parties or groups

Ballentine's Law Dictionary 109 (3d ed. 1969).

9 Clearly, lawyers serving as facilitators, consensus builders or mediators have "clients" (people who pay them for their work), but here the client is not the same as the "represented client." See the distinctions drawn in definitions of client in the Model Rules of Professional Conduct, particularly, Rule 2.2 (which until 2000 provided for a role for lawyers to act as "Intermediaries" between clients). In 2000, the ABA Ethics 2000 Commission removed Rule 2.2 (which was seen as confusing roles of representation of parties and mediation without representation and adopted, instead, Rule 2.4 (Serving as a Third Party Neutral) to explicitly recognize the lawyer who serves as a neutral. Compare Model Rules of Prof'L Conduct R. 1.12 (2003) and Model Rules Prof'l Conduct 2.4 (2003), with Model Rule for Lawyers as Third Party Neutral, pmbl. (Georgetown-CPR Commission on Ethics and Standards in ADR, (updated Jan. 2004)), at Public Policy Projects, http:// www.cpradr.org. (last visited Jan. 20, 2005).

10 Anthony T. Kronman, The Law as a Profession, in Ethics in Practice: Lawyers' Roles, Responsibilities, and Regulation 36 (Deborah L. Rhode ed., 2000). 
in democratic participatory events (like lobbying, negotiated rule-making and advocacy) but they may also be particularly well suited to facilitating such processes (and new ones), with perhaps some different orienting frameworks and some additional forms of training and education.

\section{Political Theory}

Both democratic and constitutional theorists have recently drawn attention to a variety of "crises" in our theories and practices of governance, suggesting that complexity, volatility and diversity have. led to such fragmentation of the polity that grand theories (constitutionalism, ${ }^{11}$ universal generalized agreements) and grand practices (separation of power, federalism, the administrative state) may be impossible to justify, not to mention effectively implement. One claimed solution to this modern dilemma has been to turn to what is called "democratic discourse" theory - a process "solution" to a variety of substantive governance problems. While some focus on democratic discourse in its theoretical formulations, and others focus on the best institutional forms for conducting democratic deliberation, I want to focus on the particular role of lawyers in the design and implementation of sites and processes for such discourse to occur.

For some, modern democratic theory is premised on the notion that communication, dialogue and deliberation by constituencies, citizens, voters and decision makers will produce better and more legitimate outcomes. ${ }^{12}$ New reformulations of democratic theory have recently suggested that process values are key to democratic legitimacy. ${ }^{13}$ Indeed, some go so far as to suggest

11 See e.g., Michael C. Dorf \& Charles F. Sabel, A Constitution of Democratic Experimentalism, 98 Colum. L. Rev. 267 (1998).

12 For a critique of "talking" as a democratic problem-solving process see Frederick Schauer, Talking as Decision Procedure, in Deliberative Politics: Essays on DemocRACY AND DisagreEmeNT (Stephen Macedo ed., 1999). For a concrete suggestion for how to improve the voting part of deliberative democracy, see JAMES S. FISHKIN, DEMOCRACY AND Deliberation: New Directions fOR Democratic ReForm (1991) (suggesting public opinion polling after provision of relevant information and opportunity for discussion). For some empirical verification of how these processes are effective, see, e.g., ARCHON Fung, EMPOWered Participation: Reinventing Urban Democracy (2004); Carmen Sirianni \& Lewis Friedland, Civic Innovation in America: Community Empowerment, Public Policy and the Movement for Civil Renewal (2001); Archon Fung \& Erik Olin Wright, Deepening Democracry: Institutional Innovations in Empowered Participatory Governance (2003); Thomas Beirle and Jerry Cayford, Democracy in Practice: Public Participation in Environmental Decisions (2002).

13 See, e.g., Bruce Ackerman \& James K. Fishin, Deliberation Day (2004); Deliberation and Decision: Economics, Constitutional Theory and Deliberative Democracy (Anne Van Aaken et al. eds.; 2004); James Bohman, Public Deliberation: Pluralism, Complexity, and Democracy (1996); John S. Dryzek, Deliberative Democracy and Beyond: Liberals, Critics, Contestations (2001); Deliberative Democracy (Jon Elster \& Adam Przeworski eds., 1998); James K. Fishkin \& Peter Laslett, Debating Deliberative Democracy (2003); Amy Gutmann \& Dennis Thompson, Democracy and Disagreement (1996); Jurgen Habermas, Between Facts and Norms: Contributions to a Discourse Theory of Law and Democracy (William Rehg trans., 1996); Mark Kingwell, A Civil Tongue: Justice, Dialogue, and the Politics of Pluralism (1995); Deliberative Politics: Essays on Democracy and Disagreement (Stephen Macedo ed., 1999); Robert D. Putnam, Better Together: Restoring the 
that it is only the process values about which we can have a priori agreement. ${ }^{14}$ If process is to be the foundational justification of democratic institutions, then lawyers have a great role to play in the practice of democracy as both "process architects"15 and as process managers. To the extent that modern life is characterized by greater social fragmentation, diversity, demographic and cultural pluralism, multi-party and intractable disputes ${ }^{16}$ which have created greater social complexity than many of our current political and legal institutions can effectively deal with, new forms of political and legal participation may be necessary. Where modern social and legal problems no longer lend themselves to easy two-sided contested positions for resolution either by votes in partisan legislatures or binary judgments in courts of law, ${ }^{17}$ new forms of public (and private) decision making may be necessary not only to resolve social and political conflicts, but to find policy solutions to problems of resource allocation, institution building and social and human welfare. Thus, modern theories of deliberative democracy recognize that we may need new social, political and legal forms to deal with our modern problems of social complexity.

To the extent that participation remains a cornerstone of democratic theory, new forms of participation (whether direct or mediated by agents or representatives) may require the creation of new institutions or modifications of old forms to permit optimum levels of participation for effective and legitimate outcomes. Whether tied to traditional constitutional and legal institutions, like courts, legislatures, and administrative agencies, or created new out of the particularities of specific situations (as in negotiated consensus building fora), ${ }^{18}$ lawyers have the knowledge, skills, craft and wisdom (if effectively employed) to help create and manage such institutions.

Foundational values remain contested among modern democratic discourse theorists, along fault lines in which process is itself the end or merely the means for at least provisional substantive outcomes. Theorists disagree about appropriate models of conflict and cooperation, social choice, authority, legitimacy, neutrality ${ }^{19}$ or objectivity, and distributive versus substantive social

American Community (2003); Ethan J. Leib, Deliberative Democracy in America: A Proposal for a Popular Branch of Government (2004); Iris Young, InClusion and DEMOCRACY (2002).

14 See Stuart Hampshire, Justice is Conflict (2000) (arguing that an agreement that there be fair procedures for adversarial debate on any important social issue is all that we can obtain consensus for - agreement on substantive outcomes for a just society is unlikely in any diverse society).

15 "Process Architect" is a term originally coined by both Lon Fuller and the Legal Process school legal theorists. See Menkel-Meadow, supra note 6. The term "process architect" has become more commonly used in recent writing about lawyers in negotiation and other forms of ADR. See e.g., Robert Mnookin et al., Beyond Winning: Negotiating to Create Value in Deals and Disputes (2000).

16 See generally Donald A. Schon \& Martin Rein, Frame Reflection: Toward the Resolution of Intractable Policy Controversies (1994); Lawrence Susskind \& Jeffrey Cruikshank, Breaking the Impasse: Consensual Approaches to Resolving PubLIC Disputes (1987).

17 See Menkel-Meadow, supra note 2.

18 The Consensus Building HandBook, supra note 7.

19 Bruce A. Ackerman, Social Justice in the Liberal State (Yale Univ. Press 1980). 
justice. ${ }^{20}$ The value of consent or true participation, by the governed - that "legitimate laws are authored by the citizens who are subject to them"21 seems central to any discussion of modern political decision making. Indeed, as many social and political theorists have abandoned any hope of agreeing in advance on the common good, procedural ideals of issue-by-issue deliberation and negotiation have supplanted substantive conceptions of the common good in much political philosophy.

Turning away from substantive discussions of the just and the good does not eliminate theoretical or practical debate - the terrain has shifted to what kinds of processes or procedures may best facilitate either partial or more global "agreements" about the good and the just. What is fair becomes the principal concern in these process-oriented theories. Thus, some political theorists look to "reasoned deliberation" focused on rationality, principled and rational discourse. ${ }^{22}$ Other theorists focus on explicit models of bargaining and interest or preference trading or negotiation. ${ }^{23}$ Still others concentrate on the recognition of emotional or subjective sensibilities (such as empathy and "imaginative identification") ${ }^{24}$ in the processes by which modern political actors must get things done. ${ }^{25}$ Some insist that foundational principles like American constitutionalism are essential to the legitimacy and fairness of any dispute resolution and political governance system, ${ }^{26}$ while others suggest that constitutionalism is too rigid and prevents important procedural flexibility in which process rules are negotiated along with substantive outcomes, as particular parties and problems require. ${ }^{27}$ Modern political theorists seek to describe, elaborate and in some cases, prescribe, "ideal speech conditions," 28 "ideal proceduralism,"29 "procedural justice," "faimess in procedure as an invariable value" 30 or "discourse ethics" at various levels of theoretical complexity. Others have focused on "new institutions" ${ }^{31}$ or new understandings or reconfigurations of existing governmental institutions, like courts, ${ }^{32}$ legislatures, ${ }^{33}$

20 JOHN RAWls, A ThEORY OF Justice, in Lloyd's INTRODUCTION TO JURISPRUdENCE (M.D.A. Freeman ed., 7th ed. 2001); Ronald Dworkin, Taking Rights Seriously (Harvard Univ. Press 1977); Robin West, Re-IMagining Justice: Progressive INTERPREtations of Formal Equality, Rights and the Rule of Law (Ashgate Pub. Co. 2003).

21 BoHman, supra note 13 at 5.

22 Elster, supra note 3; HABERMAs; supra note 13.

23 Elster, supra note 3.

24 HAMPShire, supra note 14 at 80.

25 Jon Elster, Alchemies of the Mind: Rationality and the Emotions (Cambridge Univ. Press 1999); Jon Elster, Solomonic Judgments: Studies in the Limitations on Rationality (Cambridge Univ. 1997).

26 Bruce Ackerman, 1 We the People, Foundations (1991); Bruce Ackerman, 2 We the People, Transformations (1998).

27 BOHMAN, supra note 13 , at 17.

28 HABERMAS, supra note 13.

29 Bohman, supra note 13 , at 17.

30 HAMPSHIRE, supra note 14 , at 4.

31 Dorf \& Sabel, supra note 11.

${ }^{32}$ Michael C. Dorf \& Charles F. Sabel, Drug Treatment Courts and Emergent Experimentalist Government, 53 VAND. L. Rev. 831 (2000); Judith Kaye, Changing Courts in Changing Times: The Need for a Fresh Look at How Courts Are Run, 48 Hastings L. Rev. 851 (1997). 
and agencies, ${ }^{34}$ often by focusing on new public and private collaborations. Still others suggest that new forms of participation will themselves generate new substantive solutions or at least contingent accommodations, recognizing that the tools used to solve problems may influence the resolutions that may be recognized. ${ }^{35}$

For Jurgen Habermas, law is made necessary by modern demands of coordination of the market sphere, administrative power and cultural and demographic pluralism. ${ }^{36}$ The rule of law permits what is not prohibited, but the rule of law (and moral norms) are legitimate if and only if all possibly affected persons could agree to them as participants in rational discourse (the "discourse principle") ${ }^{37}$ To fully participate in the discursive community, according to Habermas, there is co-origination of private liberties and public autonomy - that is, discourse can occur only if there is recognition of the essential "right" of equality of participation. We can understand equal "rights" only after we have "discussed" them and acknowledged them. Discourse itself depends on the "equal" participatory rights of each individual to have "equal standing" to propose agenda items, suggest solutions to issues on the agenda, to offer reasons (or other "arguments") ${ }^{38}$ for acceptance or rejection of solutions, to offer criticism and to have an "equal voice" in the decision. ${ }^{39}$ In some versions of discourse theory, there is an additional substantive requirement that inequality of power and resources should not "control" decision-making and disproportionately distort or "coerce" deliberation. ${ }^{40}$ How this theory can be

33 Such as in "quasi-legislating dispute resolution" or "LDR," as one commentator has called it in describing the regionalized negotiations for habitat regulations, see BRUCE BABbitT, ADR Concepts: Reshaping the Way Natural Resources Decisions ARe Made, Into the 21st Century: Thought Pieces on Lawyering, Problem-Solving and ADR (CPR Institute for Disp. Reso., 2001) (suggesting that both courts and modern legislatures cannot effectively manage multi-stakeholder natural resource allocation problems).

34 Jody Freeman, Collaborative Governance in the Administrative State, 45 UCLA L. REv. 1 (1997) [hereinafter "Freeman, Collaborative Governance"]; Jody Freeman, The Private Role in Public Governance, 75 N.Y.U. L. REv. 543 (2000) [hereinafter "Freeman, Private Role"]; Philip J. Harter, Negotiating Regulations; A Cure for the Malaise, 71 GEo. L.J. 1 (1982); Laura I. Langbein \& Jody Freeman, Regulatory Negotiation and the Legitimacy Benefit, 9 N. ENvTL L .J. 60 (2000).

35 See, e.g., Carrie Menkel-Meadow, The Lawyer as Problem Solver and Third Party Neutral: Creativity and Non-Partisanship in Lawyering, 72 TeMP. L. Rev. 785, 787 (1999) (describing the "tools to theory heuristic" which tells us that the tools or processes we use affect the outcomes we produce) (quoting Gerd Gigerenzer, Where Do New Ideas Come From? in Dimensions of CReativity 53 (Margaret A. Boden ed., 1994)).

36 HaBermas, supra note 13.

37 Habermas, supra note 13, at 107; Joshua Cohen, Reflections on Habermas on Democracy, in 12 RATIO JURIS. 385, 392 (1999).

38 While Habermas' conception of discourse theory is premised on "reasons," others have suggested that discourse can permit appeals and arguments from sources other than "reasons," such as emotions, beliefs, interests, needs, etc., depending on the context. See, e.g., Elster, Alchemies, supra note 25; Cohen, supra note 37; Carrie Menkel-Meadow, Toward Another View of Legal Negotiation: The Structure of Problem Solving, 31 UCLA L. REv. 754 (1984).

39 Cohen, supra note 37 , at 397 .

40 Both Habermas and Rawls insist on such "substantive" conditions of equal participation, at least in theory. It is hard to imagine an "actual" example of discourse or deliberative democracy in which inequality of power does not influence the decision (since the definition 
translated into practice in modern, complex and pluralistic social and legal problems is the subject of this paper.

Legal scholars and practitioners (as well as other professionals) enact these theories "on the ground" by theorizing, inventing, implementing and evaluating various forms of democratic discourse as they attempt to solve real problems in practice. For Habermas, as for other discourse theorists, problem solving occurs in several spheres, some formally constituted (through Constitutional structures and institutions, like legislatures, courts and administrative agencies) and others through more informal "circulation" of problems, ideas and solutions. In this "two track" process, public discourse in associational and deliberative settings creates, identifies and debates problems while more formal institutions approve solutions to and resolve those problems. Even the kinds of thinking or decision making which occur in different spheres may be different - some offer models of rational decision making in rather formalistic processes ${ }^{41}$ while others offer more "naturalistic" or fluid processes of deliberation and decision choices. ${ }^{42}$

Recently, a variety of political theorists and social scientists have proposed and studied specific examples of deliberative processes used in different forms of social and legal problem solving, often in highly politicized situations. Seeking to explore not only formal institutions like courts, legislatures and agencies, these students of the political process suggest that other forms may effectuate the conditions of legitimate political action where they permit the articulation of new problems and issues, experimentation and implementation of new proposals and solutions that involve participation by those affected by the decisions made. Called variously, "intermediate sites" 43 of democracy, "the informal or dispersed public sphere," "directly-deliberative polyarchy" (to institutionalize direct problem solving by citizens $)^{44}$ or "consensus building" or

of power involves the ability to control or influence other's behaviors. See RoBERT ALAN Dahl, Who Governs? Democracy and Power in an American City (Yale Univ. Press 1961); Robert A. Dahl, On Democracy (Yale Univ. Press 1998); Robert A. Dahl, How Democratic is the American Constitution? (Yale Univ. Press 2001). For an example of the more common claim that inequality of power or resources inevitably does affect the decisions that are made, see Iris Marion Young, Justice, Inclusion, and Deliberative Democracy, in Deliberative Politics, supra note 13, at 151, who argues that women on welfare were not equal participants in recent welfare reform debates.

41 John S. Hammond et al., Smart Choices: A Practical Guide to Making Better Decisions (Harvard Bus. School Press 1999); Paul Brest \& Linda Krieger, Lawyers as Problem Solvers, 72 Temp. L. Rev. 811 (1999).

42 Gary Klein, Sources of Power: How People Make Decisions (MIT Press 1998). Some distinguish deliberation (use of reasons) from bargaining (trading of preferences). Others see bargaining as a form of reasoning. See, e.g., Melvin Aron Eisenberg, Private Ordering Through Negotiation: Dispute-Settlement and Rulemaking, 89 HARV. L. Rev. 637 (1976).

43 Susan Sturm \& Lani Guinier, Learning from Conflict: Reflections on Teaching About Race and Gender, 53 J. Legal. Ed. 515 (2003); Susan Sturm \& Lani Guinier, The Future of Affirmative Action: Reclaiming the Innovative Ideal, 84 CAL. L. REv. 953 (1996).

44 Joshua Cohen and Charles F. Sabel, Directly-Deliberative Polyarchy, 3 EuR. L.J. 313 (1997); see also William H. Simon, Solving Problems v. Claiming Rights: The Pragmatist Challenge to Legal Liberalism, 46 WM. \& MARY L. Rev. 127 (2004) (contrasting legal pragmatism and problem solving to legal liberalism and rights based litigation). 
"town meeting" activities, there are both new institutional forms and new processes $^{45}$ to examine.

Those that describe such processes do not always agree about their purposes, structures or operation. Thus, for some, "consensus," or some form of agreement by participants, beyond a majority, is an essential part of the commitment. ${ }^{46}$ For others, consensus may never be possible or desirable (especially about pre-deliberation commitments). New democratic institutions are "pragmatic" because they may develop issue-specific resolutions or develop collaboration out of necessity, rather than "real" and deep agreement. For still others, democratic discourse doesn't even produce policy or decisional "outcomes," just the possibility of increased conversation and understanding. ${ }^{47}$

For Dorf and Sabel, ${ }^{48}$ for example, more localized sites of experimentation in policy initiation, analogized to corporate and organizational developments, interact with national systems of information sharing and accountability ${ }^{49}$ to produce greater citizen participation and collective problem solving, while retaining commitments to basic Constitutional allocations of power.

For others, such as James Bohman and Lawrence Susskind (scholars outside of legal studies) commitments to existing or foundational Constitutional structures are not as important as on-going negotiation and consensus about the very process that is used in deliberating about either specific issue resolution or more sustained social problem solving. In modern parlance this is often called "adhocracy" - the importance of tailoring processes to particular decision making in particular cases, without requiring or relying unnecessarily on more formal, regularized and institutionalized processes.

For still another group of theorists the crucial issue is what constitutes "proper" deliberation, both in terms of permissible discourse ("reason" vs. "non-rational" emotional, religious, and passionate appeals to needs and interests) and the processes by which differences are resolved and choices are made (reasoned argument, persuasion and acceptance or bargaining, trade and compromise).

Is democratic deliberation an end in itself (as the process theorists argue) or is it recommended because it produces better (or more legitimate) outcomes (as the utilitarians would defend it)? Can democratic discourse "resolve" moral

45 Whether such processes must be institutionalized or are better left flexible and not formalized is itself one of the interesting "practice" questions of the theory of discursive democracy. See Thomas C. Beierle \& Jerry Cayford, Democracy in Practice: Public Participation in Environmental Decisions (Resources for the Future 2002); Christine Carlson \& John Stephens, Governance and Institutionalization: How May the Institutions of Government Make Appropriate, Sustained Use of Consensus Building Processes at the Local Level? The State Level? The Federal Level? The Tribal Level, at http://www.acresolution. org/research.nsf/keyepp02-2.

46 The Consensus Building HandBook, supra note 7.

47 See, e.g., Public Conversations Dialogues on Abortion, at http://www.publicconversations.org.

48 Dorf \& Sabel, supra note 11.

${ }^{49}$ Id. 
conflicts or only "political" ones? ${ }^{50}$ Legal theorists tend to emphasize the importance of individual rights, equality and institutional settlement principles (like courts as ultimate decision makers, even if "transformed" into problem solving courts) while political theorists and practitioner philosophers are more likely to want to recognize new forms with greater direct citizen participation. ${ }^{51}$ Amy Gutmann and Dennis Thompson, however, also suggest that the proceduralists and process theorists neglect to notice how different processes and rules enact particular substantive outcomes with important moral, and economic consequences.

If there is only one thing such varied theorists seem to have in common, it is a belief that greater, wider and deeper participation in democracy and political and legal decision making will be better for our society, as well as for individuals (contra Oscar Wilde's view that the trouble with socialism (read democracy) is that it takes too many evenings/meetings). ${ }^{52}$ The unifying theme is one of articulating a vision of collaborative, cooperative social processes, in opposition to the more adversarial and competitive assumptions of Hobbesian and Madisonian theories of contest and factionalism in human deliberation. And, in other respects, the claims for deliberative democracy recapitulate old dualisms between liberalism (individualism) and democracy (republican and representative forms).

Unfortunately, while these various descriptions of deliberative democracy are appealing, they continue to refer to traditional, argumentative and dualistic conceptions of discourse. James Bohman, for example, elaborates a variation on Habermasian discourse theory by distinguishing "dialogue" from "discourse." "Dialogue" refers to a responsive process in which it is expected that reasons or arguments will invite a "response" and will remain open to constant revision as new arguments are made. The purpose of deliberation is "joint problem solving" or a discourse with "special characteristics" 53 in which there are "back and forth exchanges" in historical, cultural and interpersonal terms. ${ }^{54}$ Bohman specifies five characteristics of dialogue-as-problem-solving: 1) making explicit in argument what is often latent; 2) exchanges on differences of temporal and cultural experiences (life and group histories); 3) applications of given norms or rules to specific cases; 4) "articulation" of the relation of vague and abstract ideals to the specifics of various proposals (a sort of "thick

50 This is Gutmann \& Thompson's major concern, and they define a series of "middle democracy" issues that fall into this category - health care, welfare policy, environmental policy, affirmative action and diversity issues. See Gutmann \& THOMPSON, supra note 13. 51 John Forester, The Deliberative Practitioner: Encouraging Participatory PlanNING PROCESSES (1999) (describing participatory collaborations between professional planners and citizens).

52 OsCar Wilde, A Life in Quotes 238 (Barty Day comp. \& ed., 2000). For conflicting evidence on whether we are in fact participating in our polis more or less, compare ROBERT D. Putnam, Bowling Alone: The Collapse and Revival of American Community (2000), with Civic Engagement in American Democracy (Theda Skocpol \& Morris P. Fiorina eds., 1999).

53 Bohman, supra note 13, at 57.

54 Id. at 57-69. 
description" 55 of proposal justification) and 5) a capacity for "perspective and role taking" which permits imaginative understanding (empathy) of the "other."

These are all laudable aspirations for procedural fairness, but they are incomplete. Like Stuart Hampshire's specification of the ideal procedural value of "fair hearing of contrary claims" and contest, notions of argument and response are only partial - necessary, perhaps, but not sufficient: "Only the one most general feature of the processes of decision is preserved as the necessary condition that qualifies a process, whatever it happens to be, to be accounted as an essentially just and fair one; that contrary claims are heard." 56

These descriptions, as most descriptions of deliberative processes, continue to refer to what Hampshire calls "the universal principle of adversary argument." ${ }^{.57}$ To the extent that modern discourse theorists continue to posit adversarial, two-sided models of discourse, they are presenting incomplete and inaccurate descriptions of modern social and legal problem solving. Disagreements may exist along a spectrum of views and most modern issues present themselves with multiple challenges and forms of resolution, especially when multiple parties are involved. It is the very "multi-plexness" 58 of most modern governance problems that require discourse, but not a simple dialectical process.

Modern discourse theorists seem somewhat blinded by a permanent form of Janus-faced mask. There are "two sides" of an issue or contest: adversarial procedure and argumentation (in Hampshire's terms), moral or political "opponents" (in Gutmann and Thompson's terms ${ }^{59}$ ). Two layers of institutional communication also exist: formal-informal, ordinary and extraordinary "Constitutional" moments (Ackerman ${ }^{60}$ ), dispersed private discourse and public institutional resolution (Habermas), "local" forms of experimentalism with national bodies of information sharing and accountability monitoring (Sabel \& Dorf) or more conventional forms of federal-state divisions of labor and regulatory authority. This seemingly primitive need for dualisms in deliberative structures at both institutional and substantive levels obfuscates modern reality which often has multiple layers of issues, parties and institutions.

One would think that a Constitutional regime which recognizes, three, if not four, branches of government, ${ }^{61}$ and a procedural system which permits class actions and party intervention and interpleaders could recognize that deliberation need not be merely dualistic and indeed becomes both more participatory, and legitimate, if more difficult, when it acknowledges a greater variety of issues, parties and institutional forms for deliberative processes. Not all processes are dyadic; not all issues have only "two-sides," arguments can have many parts and any group of people can agree on some issues (wholly or partially) and disagree about others.

s5 Clifford Geertz, Thick Description: Toward an Interpretive Theory of Culture, in THE InTERPRETATION OF Cultures; SELECTED Essays (1973).

56 HAMPSHIRE, supra note 14 , at $16-17$.

57 Id. at 29.

58 Lon L. Fuller, Mediation - Its Forms and Functions, 44 S. CAL. L. ReV. 305 (1971).

59 GutManN \& ThOMPson, supra note 13, at 3.

60 ACKerman, supra note 26.

61 Peter L. Strauss, The Place of Agencies in Government: Separation of Powers and the Fourth Branch, 84 CoLuM. L. Rev. 573 (1984). 
Thus, democratic discourse theory needs to learn from dispute resolution theory, that positions and parties may be multiple, that processes of deliberation may range from principled argument to interest-based bargaining and coalitional behavior, to appeals based on emotions, faith and belief, as well as fact. These different levels of "discourse" must be "coordinated" and understood if deliberative democracy is not to be manipulated or used strategically, rather than authentically.

Here, I seek to describe some of these social, political and legal experiments in new processes and to elaborate the lawyer's role as a facilitator of deliberative democracy. Whether the lawyer must be cabined to one sphere or another (or whether there are in fact only two spheres - the formal and the informal) is one of the central concerns of this essay. For as process experts, lawyers may be particularly well suited for "translating" between spheres. ${ }^{62}$ As the moral philosopher Stuart Hampshire recently suggested, "the skillful management of conflicts is among the highest of human skills." ${ }^{63}$ Consensus building lawyering is one of the concrete ways in which the vision of deliberative democracy can be realized.

\section{Consensus Building Processes}

The terms "consensus building process," "public dispute resolution," "policy dialogues," "public conversations," "negotiated rule-making" and "facilitated problem solving conflict resolution" 64 all describe efforts to create new forms of participatory and democratic lawmaking, decision making and problem solving. What these processes have in common is an effort to bring all interested parties, called "stakeholders," together to negotiate their own process rules (which may vary from majority votes to unanimous consensus or veto power) for making decisions, either final or contingent, with structured meetings, almost always led or facilitated by an expert "third party neutral" with process expertise and often with substantive expertise as well.

From the perspective of democratic theory these processes are intended to be closer to direct democracy models (town meetings) than representative models (although there will often be "representation" of groups and constituencies, especially "surrogates" to represent parties who are "interested" but may not be organized). These processes often use small group and multiple track negotiation and decision-making processes to focus on particular issues, tasks, resource allocations, definitional issues or to develop principles and bases for decisions.

The underlying conception is Habermasian - to create "ideal speech conditions" in which citizens or interested parties communicate directly with each other and with decision makers to participate in the making of rules or deci-

62 This is, of course, a variant on de Tocqueville's argument that lawyers in the United States served the intermediary function between the governed and the governors, performed in other societies by the aristocracy. See DE TOCQUEville, supra note 1.

63 HAMPSHIRE, supra note 14 , at 35.

64 John Burton \& Frank Dukes, Conflict: Practices in Management, Settlement, AND Resolution (1990). 
sions that will affect them. In this conception, each individual or "interest" has an equal right of participation, argumentation and decision power.

The ethos is intended to be one of "collaborative," rather than "competitive" approaches to problem solving, especially where there are multiple parties and multiple interests not lending themselves to simple zero-sum distributional solutions. Inevitably, of course, coalitions may develop among and between different interest groups. Skilled facilitators and process managers are necessary to monitor "strategic" processes and insure "authentic" participation. Participants generally develop their own ground rules, which include processes for information sharing, joint fact-finding, development of expert knowledge, and rules of decision. Most consensus building professionals regard themselves as enforcers of a participatory democracy model that differs from simple majority rule, so that "minority" interests are fully heard and protected. Whether the "consensus" is purely unanimous or some other rule of decision arrived at by a group, "consensus" is meant to convey more "consent" than simple voting.

These democratic dispute resolution processes also aim to solve underlying problems, address all participants' needs and interests, as best as possible, so that the focus of decision making is both more complete, deeper and fuller than occurs in other institutional problem solving settings, like courts or legislatures. Thus, consensus building processes are often multi-disciplinary, taking account of legal requirements and standards, but focusing on issues beyond what might be denominated as "merely legal." ${ }^{65}$ Such processes are designed to develop more creative and better substantive solutions to problems, where information is shared across disciplines and approaches from outside of the conventional frame are considered. In addition to being more "creative," solutions to problems from such processes may also be more "implementable," because they have been vetted by a larger number of people and interest groups that might be affected by particular solutions.

Outcomes of such processes may vary as well, ranging from final and firm decisions, to resource allocations (i.e., block grant allocations or environmental liability), to contingent agreements, ${ }^{66}$ to simple dialogue without "result," 67 other than enhanced understanding on highly divisive issues and values conflicts. Such processes may also be used before "problems" develop, such as in construction "partnering" 68 processes, strategic planning processes, reg-neg and environmental siting.

65 See, e.g., Morning Edition: School Funds Lawsuit (NPR broadcast, Aug. 24, 2000) (Attorney General Eagly in North Carolina refers to educational practices in North Carolina which he is defending as "constitutional" but not good educational policy).

${ }^{66}$ See, e.g., Edward Scher, Negotiating Superfund Cleanup at the Massachusetts Military Reservation, in The Consensus BuIlding HandBook, supra note 7, at 259.

67 See Catherine Flavin-McDonald \& Martha McCoy, Study Circles: Moving from Acrimony to Democracy Building, 4 Disp. Resol. MaG. 14 (1998); Margaret Herzig, Public Conversations: Shifting to Dialogue When Debate is Fruitless, 4 Disp. Resol. Mag. 10 (1998); Michelle LeBaron \& Nike Carstaphen, Finding Common Ground on Abortion, in The Consensus BuILding HandBoOK, supra note 7, at 1031.

${ }^{68}$ Lindsey "Peter" White, Partnering: Agreeing to Work Together on Problems, 4 DisP. Resol. MAG. 18 (1998). 
These new processes have begun to influence traditional legal institutions. There are now multi-dimensional "problem solving" courts in family law, ${ }^{69}$ drug and vice, ${ }^{70}$ and business settings. ${ }^{71}$ Administrative agencies have adapted mediational and consensus building processes to the rule-making process as "negotiated rule-making" or "reg-neg."72 Even lawyers representing clients in adversary settings are now looking at "collaborative lawyering" 73 as an alternative model to advocacy in which lawyers commit in advance to try to solve problems through negotiation and other means and pledge to avoid polarizing litigation.

\section{Applications and Examples of Consensus Building Processes}

Modern attempts to operationalize democratic participation in contested legal and social issues are several decades old, but are only now beginning to garner legal scholarly attention. Used in such matters as municipal finance and block grant allocations, environmental siting, environmental clean-up, community and neighborhood disputes and administrative negotiated rule-making, most consensus building processes formally recognize the existence of multiple stakeholders and interested parties in dispute resolution, resource allocation and policy formation. ${ }^{74}$ What differentiates consensus building processes from other processes are the following features:

1. Agreement by parties as to operative "ground rules" (which include rules for participation, information gathering and decision rules) which are particular for the event and not "universal" (such as the Federal Rules of Civil Procedure or Robert's Rules of Order) $;^{75}$

2. Agreement by parties as to decision rules (definitions of "consensus" or super-majorities, vetoes) for agreements or recommendations (as when all a group can do is make "recommendations" to a properly constituted legal body, such as a zoning board, administrative agency or legislative body); 3 . Use of an expert "facilitator" or group of facilitators to monitor processes and in some cases, to coach parties with respect to negotiation skills, coordinate information sharing, manage meetings, develop agendas, record proceedings, prepare texts for negotiation, assess conflicts as well

69 Kaye, supra note 32.

70 Dorf \& Sabel, supra note 32.

71 See, e.g., Celia Cohen, Delaware Chancery Court Is Now Using Mediation, Nat'L L.J., Oct. 30, 2000, at B7. The London Commercial Court is a specialized court that hears only commercial cases on the theory judges will have or develop expertise and craft "businesslike" decisions.

72 See generally Freeman, Collaborative Governance, supra note 34; Freeman, Private Role, supra note 34; Harter, supra note 34; cf. Cary Coglianese, Assessing Consensus: The Promise and Performance of Negotiated Rulemaking, 46 Duke L.J. 1255 (1997); William Funk, Bargaining Toward the New Millennium: Regulatory Negotiation and the Subversion of the Public Interest, 46 Duke L.J. 1351 (1997).

${ }^{73}$ Robert W. Rack, Jr. Collaborative Lawyering: For Lawyers, It's Settle or Withdraw, 4 DisP. Resol. MAG. 8 (1998).

74 For the most comprehensive description, with examples, of consensus building events, see The Consensus Building HandBook, supra note 7.

75 Susskind has attempted to draft an alternative set of "Rules" for consensus-based decision making and group facilitation. See id. at pt. 1. 
as the underlying interests and needs of parties and often to serve as spokesperson to media or public about issues to ensure confidentiality for parties during deliberation (if appropriate) ${ }^{76}$

4. Participation of as many stakeholders (interested parties) as possible; not merely those limited by legal rules in litigation or other procedural rules; including both direct participation (where possible) and representation of constituencies;

5. Rules and processes for deliberation about proposals, as well as ratification; and

\section{Monitoring and procedures for implementation.}

Elements of these basic criteria may be modified depending on whether a consensus building event is scheduled around an ad hoc event or issue (particular litigation resolution, community dispute or budget allocation) or whether an on-going organization or agency seeks to establish different decision rules or participation goals over the long run (a governmental structure, an NGO, a new entity, such as a Truth and Reconciliation Commission, or, heaven forbid, a faculty department). Lawrence Susskind, for example, has offered a new flexible "codification" of consensus building "rules" that are easily modified for ad hoc or more permanent groups.

The key to such processes is that they are professionally developed and managed to evolve from the needs of the particular parties engaged and so are flexible. Also, once elaborated, these events provide clear rules of process, as well as decision. Consensus building is democratic because parties decide their own rules but they are also facilitated or "guided" by those who have some expertise about process ${ }^{77}$ (and sometimes the substance) - to wit, the role of lawyers! Ideally, expert facilitators can minimize the strategic gaming and bargaining $^{78}$ that may occur when unequal parties come together to deliberate. ${ }^{79}$ Of course, use of experts, whether process experts, like professional facilitators, or lawyers, as meeting managers or substantive or process experts, might seem a bit ironic in this context. These processes are designed to be participatory and democratic - why would they need experts or leaders? Some processes do indeed proceed without leadership (see Modes of Conflict Resolution Chart below) and can be considered more participatory or "grassroots," but where

76 Lawrence Susskind \& Patrick Field, Dealing with an Angry Public: The Mutual Gains Approach to Resolving Disputes (Free Press 1996).

77 Even the American Association of Law Schools has recognized the importance of process expertise in training legal educators to facilitate law school strategic planning events, as evidenced by the creation of the AALS Resource Corps.

78 See, e.g., Thomas C. Schelling, The Strategy of Conflict (1960); Leigh L. Thompson, Groups and Teams: Multiple Parties at the Bargaining Table, in THE MIND AND HEART of THE NEGOTIATOR (2d ed. 2001); Gary Goodpaster, Coalitions and Representative Bargaining, 9 OHı ST. J. on Disp. Resol. 243 (1994); Cass D. Sunstein, Deliberative Trouble? Why Groups Go to Extremes, 110 YALE L. J. 71 (2000).

79 Many consensus-building processes involve pre-event negotiation and interest-based bargaining training. For example, in the Kyoto Accords deliberations parties were given negotiation training before meetings began. Much of interest-based bargaining in labor relations now depends on parties being trained in interest-based negotiations before actual negotiations begin. See Richard E. Walton et al., Strategic Negotiations: A Theory of Change in Labor-Management Relations (1994). 
some "ordering" is necessary to structure democratic deliberation, use of process experts, who make no substantive recommendations or decisions, should be consistent with these more flexible processes. This is wholly consistent with modern conflict resolution theory, as well as Lon Fuller's older and more basic notions of "process pluralism" and "institutional competence" where different kinds of third parties are used in different kinds of processes, with different party concerns and structures. ${ }^{80}$

Successful consensus building exercises have accomplished such things as negotiated agreements for monetary allocations, clean-up procedures for environmental Superfund sites, ${ }^{81}$ water management, ${ }^{82}$ site location of unpopular public and private land-uses (airports, ${ }^{83}$ waste dumps, commercial enterprises, parking garages, half-way houses), city charter drafting, ${ }^{84}$ strategic planning for states, court systems, municipalities, universities, private corporations and public governmental bodies, as well as NGO's and non-profit entities, negotiated rule-making in environmental use,${ }^{85}$ transportation, ${ }^{86}$ Indian affairs, ${ }^{87}$ taxation, health and safety regulations, environmental clear air and water standards, medical and ethical decision-making, ${ }^{88}$ inter-group relations and community disputes, statewide regulations, workplace relations, ${ }^{89}$ political and religious reconciliation processes ${ }^{90}$ and most significantly, when it works, international cross border and internal peace initiatives. ${ }^{91}$ Consensus-building-like processes have even been used to facilitate both "public" and "private" conversations about such hotly contested political and moral matters as abortion, ${ }^{92}$ affirma-

${ }^{80}$ Fuller, supra note 6.

81 Scher, supra note 66.

82 Janet C. Neuman, Run, River, Run: Mediation of a Water-Rights Dispute Keeps Fish and Farmers Happy - For a Time, 67 U. CoLo. L. Rev. 259 (1996).

83 Peter Driessen, Activating a Policy Network: The Case of Mainport Schiphol, in THE Consensus Building HandBook, supra note 7, at 685.

${ }^{84}$ Kate Connolly, From City Hall to the Streets: A Community Plan Meets the Real World, in The Consensus Bullding Handbook, supra note 7, at 969; John Parr, The Chattanooga Process: A City's Vision is Realized, in The Consensus Bullding HandBook, supra note 7 at 951; Susan L. Podziba, The Chelsea Charter Consensus Process, in The Consensus BuILding HANDBOOK, supra note 7, at 743.

85 Freeman, supra note 34.

86 Christine Carlson, Transportation Rule-Making in Oregon, Policy Consensus INSTITUTE (2000).

87 Jan Jung-Min Sunoo \& Juliette A. Falkner, Regulatory Negotiations: The Native American Experience, in The Consensus BuIlding HandBook, supra note 7 at 901.

88 Managing in Academics: A Health Care Model (Jill Ridky \& George F. Sheidon eds., 1993); Mark E. Meaney, A Deliberative Model of Corporate Medical Management, 28 J. L. MEd. \& ETHICS 125 (2000).

89 Cynthia L. Estlund, Working Together: The Workplace, Civil Society, and the Law, 89 Geo. L. J. 1 (2000); Susan Sturm, Second Generation Employment Discrimination: A Structural Approach, 101 Colum. L. Rev. 458 (2001).

90 See David Brubaker, Organizational Trauma Recovery: The "God's Fellowship Community Church" Reconciliation Process, in The Consensus Building Handbook, supra note 7 , at 1051 .

91 See Words Over War: Mediation and Arbitration to Prevent Deadly Conflict (Melanie C. Greenberg et al. eds., 2000); see also George J. Mitchell, Making Peace (2000).

92 See Michelle LeBaron \& Nike Carstarphen, Finding Common Ground on Abortion, in The Consensus Building HandBook, supra note 7, at 1031. 
tive action, ${ }^{93}$ and AIDS-HIV, ${ }^{94}$ where goals of the process may be different from undertaking some action (such as reducing violence at abortion clinics) and can include simply "reframing" of issues and making efforts at mutual understanding.

As some examples, consider the use of consensus building processes at two ends of a spectrum - the first, action-oriented with a goal of drafting a regulation or agreeing to take some action. Those negotiated rule-making enterprises which have been successful ${ }^{95}$ have required hundreds of hours of information gathering, meeting time, separate caucus sessions, meetings in plenaries and meetings with constituencies, but the theory is that complex deliberative processes with much time invested up-front leads to rules with greater inputs, if more complex outputs, and therefore greater compliance.

At the other end of the spectrum, consider the efforts to manage deliberative conversations about affirmative action and abortion. In those which I participated and led during California's debate about Proposition 209 (voter disapproval of the use of governmental affirmative action plans in education, employment and government contracting), efforts were made to ask participating parties to state their views, the origins, data or experiences from which their views were derived, their own ethnic, gendered and racial background, what grey areas or questions they had about their own views, as well as others. Such efforts to create "structured conversations" around highly divisive issues, away from the two-sides debate mode ${ }^{96}$ elaborated more complex views than either pro-or-con affirmative action (including group variations in use of affirmative action in education, employment, contracting and for different indicia of "affirmative" and group relief).

Thus, formats which provide greater opportunities for more subtle and complex views to be expressed enable the complexities of social and legal issues to be explored and "cross-interests" to be recognized. It was deeply unfortunate that as a polarized election required the populace to vote up or down on a highly complicated social and legal issue, our affirmative action fora were demonstrating that large members of the public and interested parties (students, government officials, and private contractors) could actually be educated to see the complexities of the issue as they interacted more with people of different views who might be affected both "positively" and "adversely" by particular legal actions. The Proposition 209 election, the law it "enacted" and the lawsuits which followed, cut, perhaps, with too blunt a knife, issues that might have been dealt with more effectively in a longer and more variegated issue discussion with more subtle and varied rules for different contexts. ${ }^{97}$

93 See Menkel-Meadow, supra note 2, at 34-35.

94 See Michael A. Hughes et al., Facilitating Statewide HIV/AIDS Policies and Priorities in Colorado, in ThE Consensus BuILdING HANDBook, supra note 7, at 1011.

95 Environmentalists, social scientists and administrative law scholars continue to debate the available data on the success of these proceedings. See, e.g., Coglianese, supra note 72; Freeman, supra note 34.

96 See Deborah Tannen, The Argument Culture: Moving from Debate to Dialogue (1998) (describing how agnostic debate has marred public discourse in the media, education, and politics, as well as in the legal system).

97 To contrast legal and more consensus based forms of decision making see Symposium, The Meanings of Merit: Affirmative Action and the California Civil Rights Initiative, 23 
In one of the most interesting examples of the differences in group deliberative processes, Jon Elster has been analyzing the process differences in Constitution formation. From his studies of both American and French constitution making, ${ }^{98}$ he suggests that there are significant differences between processes based on principles and reasons (which can lead to rigid, non-bargainable disputes and extreme outcomes) versus interest-based bargaining (where trades, compromises and log-rolling is possible). There are also differences between those processes that are public (and lead to immovable stances) and processes that are secret (where compromises and changes in positions can be negotiated). Thus, Elster argues that the success of the American constitutional processes may be attributable, at least in part, to particular processes choices (secrecy, and committee, rather than public plenary, sessions) which many political theorists would label second best because of the covert interest bargaining, rather than public and principled argument. Pragmatists, on the other hand, would recognize the greater stability of such "bargained for" and interestbased outcomes. The American constitutional deliberations, characterized by committees, secrecy and interest-based trades (including compromises on slavery, urban-rural representation and other matters) produced a constitution far more robust ${ }^{99}$ (if perhaps more unjust) than the French constitutional process with its plenary, and public, if more principled, processes. What this should teach us is that democratic discourse processes can and should take different forms, depending on the issues at stake and the understandings we now have about how particular processes themselves affect substantive outcomes and whether they are designed to be contingent and temporary or more constitutive.

Below, I have built upon Elster's observations about three different "modes of discourse" - principled (based on reasoned argument), bargaining and preference trading of interests and expression of emotions, religious or other values ("passions") - and the different kinds of processes that might be employed in making decisions or resolving conflicts - (public/private; plenary/ committee; constitutive/permanent/ad hoc; expert-facilitated/naturalisticleaderless) - to sketch out some examples of different kinds of decision making and government processes in different settings. This chart graphically represents the kind of process diversity or pluralism that might be used in different settings, depending on what kinds of groups are trying to make what kinds of decisions (e.g., temporary, permanent; full constituencies, representatives). Other categories of groups or kinds of decisions can easily be elaborated and I invite readers to consider the multiplicity of kinds of issues, conflicts, problems and disputes that individuals and the full polity must resolve if we are to live successfully together. My point in elaborating these examples is to suggest that in conflict resolution, problem solving, and democratic decision-making, one size or shape of process does not (and should not) fit all. While our constitution suggests the importance of separation of powers in three branches of govern-

Hastings L. Q. 921 (1996). Consensus-building processes and the outcomes they deliver raise issues of rules versus standards (discretion) and generalized or universal principles versus contextual specificity and adaptability.

98 See Elster, supra note 3.

99 With, of course, the interruption of a Civil War, and then a series of crucial amendments which revised the document, if not all civic practices. 
ment and federalism suggests multiple sites and levels of decision-making, many kinds of decisions that affect us today need greater flexibility than formal processes may permit. The following chart or taxonomy of types of processes, with examples, is intended for us to see the possible variability in human decision processes.

\section{MOdes of CONFLICT Resolution ${ }^{100}$}

\begin{tabular}{|c|c|c|c|}
\hline Mode of Discourse & Principled (Reasons) & $\begin{array}{l}\text { Bargaining } \\
\text { (Interests) }\end{array}$ & $\begin{array}{l}\text { Passions (needs/ } \\
\text { emotions/religion }\end{array}$ \\
\hline \multicolumn{4}{|l|}{ Forms of Process } \\
\hline Closed & $\begin{array}{l}\text { Some court } \\
\text { proceedings; arb. }\end{array}$ & $\begin{array}{l}\text { Negotiation-US } \\
\text { Constitution; } \\
\text { diplomacy. }\end{array}$ & $\begin{array}{l}\text { Mediation (e.g. } \\
\text { divorce) }\end{array}$ \\
\hline Open & $\begin{array}{l}\text { French Constitution; } \\
\text { courts; arb }\end{array}$ & $\begin{array}{l}\text { Public Negotiations; } \\
\text { some labor }\end{array}$ & Dialogue Movement \\
\hline Plenary & French Constitution & Reg-Neg. & Town meetings \\
\hline Committees & $\begin{array}{l}\text { Faculty committees; } \\
\text { Task groups }\end{array}$ & $\begin{array}{l}\text { US Constitution/US } \\
\text { Congress }\end{array}$ & $\begin{array}{l}\text { Caucuses-interest } \\
\text { groups }\end{array}$ \\
\hline Expert/Facilitator & Consensus Building & Mini-Trial & Public Conversations \\
\hline $\begin{array}{l}\text { Naturalistic } \\
\text { (Leaderless) }\end{array}$ & & & $\begin{array}{l}\text { Grassroots } \\
\text { Organizing/WTO } \\
\text { protests }\end{array}$ \\
\hline Permanent & $\begin{array}{l}\text { Government, } \\
\text { Institutions }\end{array}$ & \begin{tabular}{|l|} 
Business \\
Organizations, Union
\end{tabular} & $\begin{array}{l}\text { Religious Org; AA, } \\
\text { WW }\end{array}$ \\
\hline Constitutive & UN, National Const. & $\begin{array}{l}\text { Nat. Const./Prof. } \\
\text { Assoc. }\end{array}$ & $\begin{array}{l}\text { Civil justice } \\
\text { movements, peace }\end{array}$ \\
\hline Temporary/Ad Hoc & $\begin{array}{l}\text { Issue org./social } \\
\text { justice }\end{array}$ & Interest groups & $\begin{array}{l}\text { Yippies, New Age, } \\
\text { vigilantes }\end{array}$ \\
\hline
\end{tabular}

Principles $=$ reasons, appeals to universalism, law

Bargaining = interests, preferences, trading, compromises

Open $=$ public or transparent meetings or proceedings

Closed $=$ confidential, secret process or even outcomes (settlements)

Plenary $=$ full group participation, joint meetings

Committees $=$ task groups, caucuses, parts of the whole

Expert $=$ facilitator-led by expertise (process or substantive or both)

Naturalistic $=$ leaderless, grassroots, ad hoc

Permanent (organizational, institutional),

Constitutive ("constitutional"),

Temporary/ad hoc groups or disputants

Some predicted effects of process on outcome:

Closed (confidential) proceedings allow more expression of interests, needs and passions $=$ More "honest" and candid"-allow more "trades", less posturing, open to vulnerability

Open (transparent) proceedings require more principled/reasons justifications/ produce more rigidity

100 Partially derived from categories specified by Jon Elster, Strategic Uses of Argument, in Barriers to Conflict Resolution (Kenneth Arrow et al. eds., 1995). 


\section{Role(s) of Lawyers in Consensus Building and Deliberative Processes}

Many of the examples of actual consensus building processes cited above were led and participated in by a great variety of citizens, parties, and interested stakeholders, as well as by particular kinds of experts. In my view, however, lawyers have many important roles to play in these efforts to engage the citizenry in more deliberative events, which govern their lives. Obviously, lawyers traditionally play roles as advocates and representatives of constituencies in both formal and less formal proceedings at which governance decisions and actions may be taken. ${ }^{101}$ This is the all important conventional role, though I think even here conventional adversary lawyers may need to adopt different approaches to representation and advocacy in an environment where "positions," interests and needs may become more dynamic as the processes continue. Consensus building processes are designed to change all parties' views of what they need and what is possible - they are not effective when parties maintain the same position and simply argue "from reason" or "law" that they are "right." By definition, a consensus building process is convened when there is a need to organize group acceptability or legitimacy about a particular action, decision or policy outcome. The lawyer who can problem solve creatively ${ }^{102}$ may better serve a client in a consensus building environment than one who argues or advocates well.

More importantly, I want to suggest here that lawyers may be particularly well suited to the design, management and facilitation of consensus building processes, especially those which implicate law, such as environmental, regulatory, governance, land-use and other "legal" problems. It might actually facilitate a process to have legal experts, as well as process and substantive experts, who can respond to questions of legality, drafting and implementation issues. And, lawyers who have studied procedure and have mastered logical and deductive, as well as inductive, thinking can often keep unruly democracy in some kind of structured order. ${ }^{103}$ Lawyers are particularly good at issue-spotting and ordering, seeing "both" (or, as I prefer, "all") sides of an issue and organizing presentations of materials. They are also professionally trained to investigate, seek and organize information, even if, unlike scientists, they do not "produce" the information or knowledge. Some of these traditional lawyering skills are particularly salient in designing and implementing consensus building or stakeholder negotiation meetings. They must be "married" to other skills (listening, facilitating, reframing) to be most effectively employed in these new settings.

\footnotetext{
101 See Charles F. Sabel \& William Simon, Destabilization Rights: How Public Law Litigation Succeeds, 117 HARV. L. REV. 1015 (2004) (describing transformation of public interest litigation from rights-based challenges to more "experimentalist" negotiated interventions in governmental agency action, with more stakeholder participation and measured accountability).

102 See Carrie Menkel-Meadow, Aha? Is Creativity Possible in Legal Problem Solving and Teachable in Legal Education?, 6 HaRv. Negot. L. Rev. 97 (2001).

103 See Dwight Golann \& Eric E. Van Loon, Legal Issues in Consensus Building, in THE Consensus BuILding HandBooK, supra note 7, at 495.
} 
At the same time, if lawyers are to be fruitfully employed in such complex, multi-party events of democratic deliberation, they must be taught different, additional things than they are taught now ${ }^{104}$ - including the economic, sociological and psychological theories and empirical verities of group behavior, the social and psychological dimensions of human interaction (and more prosaically, meeting management, negotiation and the sorts of things that are taught in business and public policy, schools) and the intellectual breadth to manage more than oppositional, binary thinking. ${ }^{105}$ At its most difficult, lawyers will have to perform in roles requiring "neutrality" and so-called "objectivity" taken from more mediational roles than those of the more familiar advocate. This has implications for the ethical rules and practice norms which govern us and assume that advocacy (or at least partisanship, even in the transactional role) is our norm. ${ }^{106}$

I do not want to suggest that only lawyers can perform these functions of design, facilitation, or representation in these new forms of participatory decision making. Most of the first generation of consensus building professionals were not lawyers (e.g. Lawrence Susskind, a city planner by training; Peter Adler, a sociologist by training); many are community organizers, social workers, psychologists, scientists and have training in skills and substantive knowledge that are also well suited to these more flexible forms of decision making. Nevertheless, I think legal training, if properly supplemented with new skills training (as legal clinicians have spent the last three decades accomplishing), is particularly appropriate for integrating substantive legal rights, technical legal procedural requirements and greater flexibility in social and legal problem solving. Many law schools have already recognized this, in the growth of conflict resolution and more broadly based legal problem solving curricula. ${ }^{107}$

\section{Conclusions and Implications}

If more participatory models of democracy are to be generated, experimented with and evaluated, there is much to recommend the use and adaptation

\footnotetext{
104 And of course, we have a new textbook to teach them, see Carrie MEnKEL-Meadow ET al., Dispute Resolution: Beyond the Adversarial Model (2005).

105 If law "sharpens the mind by narrowing it." (Oliver Wendell Holmes, Jr., A Man and the Universe, Address Before the Brown University Commencement (1897), in THE MIND AND Farth of Justice Holmes 36 (Max Lerner ed. 1943), also in The Collected Works of Justice Holmes 518 (Sheldon M. Novick ed., 1995) (attributing the quote to Edmund Burke)), then will we make lawyers less acute by asking them to hold many more "positions" or "arguments" in their heads at one time?

106 I have written extensively on the issue of how our lawyer's ethics rules will have to be re-crafted to reflect such new roles if we are to be recognized as lawyers performing these roles. See, e.g., Carrie Menkel-Meadow, The Lawyer as Consensus Builder: Ethics for a New Practice, 70 TenN. L. Rev. 63 (2002); Carrie Menkel-Meadow, Ethics and Professionalism in Non-Adversarial Lawyering, 27 FLA. ST. U. L. REv. 153 (1999); Carrie MenkelMeadow, The Silences of the Restatement of the Law Governing Lawyers: Lawyering as Only Adversary Practice, 10 Geo. J. Legal EthIcs 631 (1997).

107 The Center for Public Resources Institute for Dispute Resolution awards an annual prize for innovation in Problem Solving Education in law schools. See Awards Program at http:// cpradr.org (last visited Jan. 20, 2005). See also, Carrie Menkel-Meadow, Dispute Resolution: Raising the Bar and Enlarging the Canon, 54 J. LEgAL. EDUC. 4 (2004).
} 
of the quasi-legal processes of consensus building processes currently in use at all levels of government, policy formation and organizational management. The advantage of some of these forms of consensus building is that they are flexible, but structured, drawing on their own ground-up developed procedural rules and substantive rules of decision and grounds for substantive enactment. Many of these processes look different from conventional legal processes - they all involve more players, parties and stakeholders than litigation, legislation and administrative regulation. They often result in contingent and complex "agreements." Their relation, both at a process level and at the substantive level, to formal governmental structures remain uncertain in many cases and "experimentalist," as others have called them. Nevertheless, I think there is exciting substantive legal work to be done to attempt to understand how more participatory processes might substitute for or supplant some of our traditional institutions that are rendered inoperable by polarized "grid-lock" or conventional issue stand-offs. For my part, I am interested in exploring how those with legal training can harness what they already know to learn how to facilitate and "manage" these new processes, not only as "architects of process," but as "architects of participatory democracy." I have seen it work and I am interested in adding to the lawyer's repertoire the ability to create new processes and institutions and to participate in them to provide more participatory and legitimate outcomes and more humane processes. If lawyers are to join these efforts in creating and participating in new forms of decision making and problem solving, then we must consider how we are to expand our conceptions of "thinking or acting" like a lawyer. 